\title{
Teacher coping strategies as factor of child's success in educational process
}

\author{
Mikhail Yurievich Kuzmin ${ }^{1 *}$, Elena Ivanovna Mironova $^{2}$, and Anastasia Andreevna \\ Kiseleva ${ }^{3}$ \\ ${ }^{1}$ Irkutsk State University, Faculty of Psychology, Irkutsk, Russia \\ ${ }^{2}$ Irkutsk State University, Department of Foreign Languages for Non-Linguistic Areas of Training, \\ Irkutsk, Russia \\ ${ }^{3}$ Institute for the Development of Education, Department of Pedagogy and Psychology, Irkutsk, \\ Russia
}

\begin{abstract}
The authors analyze various approaches to the problem of factors that determine a child's success in the educational process. The contradictory nature of modern research on this issue is established. There is no consensus on the impact of coping strategies on a child's academic and creative success. The purpose of the study is to determine coping strategies of teachers with various experience levels and specialties that affect the success of children in the educational process. The sample consists of 314 teachers in Irkutsk with various experience levels and specialties. The authors utilize the methods "The Ways of Coping Questionnaire" by R. Lazarus and S. Folkman, "Methodology for determining individual coping strategies" by E. Heim as well as the analysis of the teachers' professional results submitted for certification. It is found that the success of students depends on the coping strategies used by their teachers of various experience levels and specialties. In general, students are more successful if pedagogues use productive coping mechanisms. However, in some cases, due to the specialty and experience of teaching staff, unproductive copings can be efficient for learning. For subject teachers, the "Distancing" strategy can be efficient, which is an unproductive coping strategy. At the same time, the strategy "Seeking social support", which is a productive coping mechanism, is inefficient for teachers of additional education. The results obtained are compared with other authors' conclusions (W.F. Admiraal, K.C. Herman, M.M. Kashapov, etc.). The authors explain the discovered features of coping mechanisms for the success of children. The limitations of the study and possible further research areas are discussed.
\end{abstract}

Keywords: coping strategies; success; educational process, teacher.

\section{Introduction}

A child's success in the educational process is a complex interdisciplinary phenomenon studied both in pedagogy and in psychology. There are various manifestations of success as

*Corresponding author: mirroy@mail.ru 
well as its different criteria and factors. Among them are intellectual giftedness [1], inclinations [2], assessing the efficiency of the result of one's activities [3], the teacher's professionalism $[4,5,6]$, etc. In the study, we consider how a teacher's coping strategies can determine the success of students in the educational process. The teacher, having coped with stress, will more efficiently help students fulfill their potential [7,8]. The teacher's inability to overcome stressful situations, on the contrary, leads to a deterioration in the students' results $[9,10]$.

This assumption about the relationship between the teachers' coping mechanisms and the student's success in the educational process is reflected in foreign studies $[7,8,11]$. However, these works do not take into account the specific features of the pedagogue's work and the experience level. In this article, we decided to clarify how teacher's coping skills, depending on their experience level and specialty, affect the child's success in the educational process.

\section{Methods}

The study was conducted by the Irkutsk Institute for Education Development. The sample consisted of 314 subjects (90 preschool educators, 138 subject teachers, and 86 teachers of additional education; 86 teachers with less than three years of experience, 99 teachers with three to ten years of experience, and 129 teachers with more than 10 years of experience).

To study coping strategies, we used "The Ways of Coping Questionnaire" by R. Lazarus and S. Folkman [12] and "Methodology for determining individual coping strategies" by E. Heim [13]. To investigate the success of children, the results presented by teachers for certification were used. For all teachers, such indicators were selected as "The number of winners and medalists of Olympiads and competitions", "Officially recorded achievements of students according to the data of various external attestations", "The efficiency of using modern educational technologies and methods", "Sustainable results of mastering educational programs by students", "The total number of participants in Olympiads and competitions". For elementary school teachers and subject teachers, the indicator "Quality of teaching" was additionally used, and for teachers of additional education - "The presence of students who continued to study the subject".

The data were processed using the Mann-Whitney U test, Kruskal-Wallis H test, and $\chi^{2}$ test, as the distribution of values was not normal. The calculations were performed using IBM SPSS 21.

\section{Results}

First, we analyzed the coping indicators of teachers in various specialties. It turned out that all of them, excluding the strategies "Confrontive coping" and "Distancing", significantly differ in each of the groups of teachers (H-test from 21 to 83.98, p <0.01): for subject teachers, the indicators are significantly more prominent than among elementary school teachers, and among the latter, more than among teachers of additional education. No differences were found according to E. Heim's method.

Then we analyzed the indicators of children's success depending on the experience level and the specialty of the teachers. We did not find any dependencies on the specialty. However, the results of students depend on the length of time for which the teacher has been carrying out educational activities $\left(\chi^{2}=139.96\right.$ for the indicator "Winners and medalists of Olympiads and competitions", $\chi^{2}=52$ for the indicator "Officially recorded achievements of students", $\chi^{2}=103$ for the indicator "Efficient application of educational technologies", $\chi^{2}=109$ for the indicator "Sustainability of the results of mastering 
programs", $\chi^{2}=78$ for the indicator "Students who continue their studies of the subject", $\chi^{2}$ $=117$ for the indicator "Participants of Olympiads" and $\chi^{2}=125$ for the indicator "Quality of education", $\mathrm{p}<0.01$ ). That is, the more experienced the teacher, the more winners of various Olympiads the teacher has, the higher the quality of teaching and the sustainability of the results.

Moreover, we examined how the students' achievements differ depending on the intensity of the coping strategies of their teachers. It turned out that the indicator "Quality of teaching" of students is higher among teachers who use productive strategies "Acceptance of responsibility" $\left(\chi^{2}=7.63, \mathrm{p}<0.02\right)$, "Seeking social support" $\left(\chi^{2}=6.78, \mathrm{p}\right.$ $<0,03)$, "Planful problem solving" $\left(\chi^{2}=7.33, \mathrm{p}<0.02\right)$ and "Positive reappraisal" $\left(\chi^{2}=\right.$ $7.71, \mathrm{p}<0.02)$. Teachers who prefer the "Self-control" strategy have more winners and medalists of Olympiads and competitions $\left(\chi^{2}=6.76, \mathrm{p}<0.03\right)$, and the efficiency of using modern technologies is higher $\chi^{2}=6.32, \mathrm{p}<0.05$ ). Students demonstrate a higher quality of learning as well as show better results in Olympiads and competitions with pedagogues using productive coping strategies.

Finally, we analyzed the specific way in which the coping strategies of teachers with different experience levels and specialties impact student success. For teachers with less than three years of experience, the use of the strategies "Positive reappraisal" and "Selfcontrol" proves inefficient: the indicators "Efficiency of using modern educational technologies and methods" $\left(\chi^{2}=6.02, \mathrm{p}<0.05\right)$ and "Sustainability of learning" $\left(\chi^{2}=6.13\right.$, $\mathrm{p}<0.05)$ are lower. On the contrary, the coping strategy "Confrontive coping" allows one to better use modern educational technologies $\left(\chi^{2}=7.39, \mathrm{p}<0.01\right)$. For teachers with three to ten years of experience, with a lower intensity of coping mechanisms "Confrontive coping" and "Escape-avoidance", the indicators "Quality of teaching" $\left(\chi^{2}=7.29, p<0.02\right)$ and "Number of participants in Olympiads" $\left(\chi^{2}=6.61, \mathrm{p}<0.03\right)$ increase, and with more than 10 years of experience, the intensity of the coping strategy "Confrontive coping" leads to a decrease in the number of winners and medalists of the Olympiads $\left(\chi^{2}=6.1, p<0.05\right)$, fewer students have officially recorded achievements $\left(\chi^{2}=8.61, p<0.01\right)$. At the same time, the strategies "Self-control", "Seeking social support" and "Positive reappraisal" increase the indicator of the quality of student learning $\left(\chi^{2}=6.53, \chi^{2}=8.06, \chi^{2}=10.9\right.$, respectively, $\mathrm{p}<0.01)$.

According to E. Heim's method, teachers with less than three years of experience using adaptive emotional coping mechanisms have a higher quality of student learning $(U=21, p$ $<0.05$ ), and when the teachers use less productive and unproductive cognitive coping mechanisms, students' results on Olympiads are lower $(U=23, U=19$, respectively, $p$ $<0.01)$. Teachers with three to ten years of experience with pronounced emotional and behavioral coping mechanisms have a higher quality of teaching $(U=324, p<0.05)$, and when the teachers use relatively productive strategies, the sustainability of results is lower $(\mathrm{U}=303, \mathrm{p}<0.01)$.

For subject teachers, the "Distancing" coping strategy proved to be comparatively efficient for achieving success in Olympiads and competitions and for the sustainability of results $\left(\chi^{2}=9.22, \chi^{2}=6.58\right.$, respectively, $\left.p<0.01\right)$; the intensity of coping mechanisms "Planful problem solving" and "Positive reappraisal" is associated with an increase in the quality of learning $\left(\chi^{2}=8.74, \chi^{2}=10.96\right.$, respectively, $\left.\mathrm{p}<0.01\right)$. For teachers of additional education, on the contrary, the strategy "Seeking social support" is less efficient: there are fewer competition winners $\left(\chi^{2}=6.75, p<0.01\right)$, and participants $\left(\chi^{2}=6.01, p<0.05\right)$. The strategy "Escape - avoidance" is also inefficient - there are fewer participants in competitions $\left(\chi^{2}=7.25, \mathrm{p}<0.02\right)$ and students who continue studies in the chosen field $\left(\chi^{2}\right.$ $=7.47, \mathrm{p}<0.02)$. Finally, primary school teachers who use the "Accepting responsibility" strategy more often have students showing more sustainable results $\left(\chi^{2}=5.74, p<0.05\right)$. 
According to E. Heim's method, subject teachers with pronounced adaptive cognitive coping strategies have more students who have officially recorded achievements $(U=1644$, $\mathrm{p}<0.03$ ), and for pronounced relatively productive strategies, the opposite is true ( $\mathrm{U}=$ $1525, \mathrm{p}<0.03)$. Pupils of primary school teachers who use productive cognitive coping have a higher quality of education $(\mathrm{U}=139, \mathrm{p}<0.03)$. Finally, for teachers of additional education who use productive emotional coping, fewer students take part in competitions $(\mathrm{U}=143, \mathrm{p}<0.05)$ and vice versa if the teachers use relatively productive cognitive coping mechanisms $(\mathrm{U}=140, \mathrm{p}<0.05)$. The number of students continuing to study the subject also increases if such teachers use unproductive cognitive coping $(U=90, p<0.04)$.

In general, we can conclude that the developmental results of students differ depending on the coping strategies used by their teachers of various experience levels and specialties. Student success is usually higher when teachers use productive coping. However, in some cases related to the specialty, coping strategies that are recognized as unproductive can also be efficient.

\section{Discussion}

With teachers who use productive coping strategies, students are more successful: more likely to get Bs and As, and also showing higher results in Olympiads and competitions. At the same time, depending on the experience level and specialty, various coping strategies affect the success of students: for teachers with little experience less productive strategies can be efficient, for subject teachers the strategy "Distancing" can be efficient, and for teachers of additional education the strategy "Seeking social support".

We have not found any works in modern psychology linking the success of student learning and specific coping strategies used by teachers. Some works [7, 8, 11, 14] establish a connection in general, without identifying specific methods of coping.

\section{Conclusion}

In our previous studies $[15,16]$, we established the specific features of coping strategies used and their efficiency among teachers, depending on the experience level and specialty. In this study, we attempted to discover the influence of these coping strategies on the child's success in the educational process. However, success was assessed using a limited number of indicators reflected in the certification files. In future studies, we plan to both increase our sample and take a wider set of indicators reflecting success in the educational process.

\section{References}

1. R.I. Kuzmina, Aktualnye Problemy Gumanitarnykh i Estestvennykh Nauk, 8(2), 146154 (2015)

2. V.D. Shadrikov, Psikhologicheskii Zhurnal [Psychological Journal], 4(5), 14-19 (1983)

3. O.V. Birina, Fundamentalnye Issledovaniya [Fundamental Research], 8(2), 438-443 (2014)

4. D. Blazar, M.A. Kraft, Educ Eval Policy Anal, 39(1), 146-170 (2017). https://doi.org/10.3102/0162373716670260.

5. S. Gershenson, Education Finance and Policy, 11(2), 125-149 (2016). https://doi.org/10.1162/edfp_a_00180 
6. T.L. Klyachko, E.A. Semionova, G.S. Tokareva, Voprosy Obrazovaniya [Education Issues], 4, 71-92 (2019). https://doi.org/10.17323/1814-9545-2019-4-71-92

7. W.M. Reinke, K.C. Herman, M. Stormont, Journal of Positive Behavior Interventions. 15, 39-50 (2013). https://doi.org/10.1177/1098300712459079

8. W.F. Admiraal, F.A.J. Korthagen, T. Wubbels. British Journal of Educational Psychology, 70(1), 33-52 (2000). https://doi.org/10.1348/000709900157958

9. H.K. Frank, W. Ineke van der Veen, A. Bert Dijkstra, R. Maslowski, Theory \& Research in Social Education, 48(1), 101-119 (2020). https://doi.org/10.1080/00933104.2019.1651682.

10. M. Ulug, M.S. Ozden, A. Eryilmaz, Social and Behavioral Sciences, 30, 738-742 (2011). https://doi.org/10.1016/j.sbspro.2011.10.144

11. K.C. Herman, J. Hickmon-Rosa, W.M. Reinke, Journal of Positive Behavior Interventions, 20(2), 90-100 (2018). https://doi.org/10.1177/1098300717732066.

12. T.L. Kryukova, E.V. Kuftyak, Zhurnal Prakticheskogo Psikhologa, 3, 93-112 (2007)

13. E. Heim, Psychotherapie, Psychosomatik, Medizinische Psychologie, 38(1), 8-18 (1988)

14. M.M. Kashapov, Chelovecheskii Faktor: Sotsialnyi Psikholog, 2(38), 90-101 (2019)

15. A.A. Kiseleva, V.V. Kozlov, M.Yu. Kuzmin, Izvestiya Irkutskogo gosudarstvennogo universiteta. Seriya Psikhologiya, 27, 45-57 (2019). https://doi.org/10.26516/23041226.2019.27.45.

16. A.A. Kiseleva, V.V. Kozlov, M.Yu. Kuzmin, Integratsiya obrazovaniya, 24(4), 641655 (2020). https://doi.org/10.15507/1991- 9468.101.024.202004.641-655. 